\title{
ABBREVIATION AS A METHOD OF FORMING CHINESE MILITARY TERMS
}

\author{
Nargiza Imomiddinova
}

Independent Researcher, Tashkent State University Of Uzbek Language And Literature Named After Alisher Navoi, Uzbekistan

\section{ABSTRACT}

This article is devoted to the abbreviation method, which is one of the most effective ways to form terms. The article analyzes polysyllabic terminological combinations in the Chinese military vocabulary by dividing them into word-formation models. The examples also cover abbreviations of full, incomplete, and mixed types. Appropriate conclusions are drawn about relatively productive models for constructing abbreviated military terms.

KEYWORDS: - Military term, military vocabulary, abbreviation, simple abbreviation, synthetic abbreviation, terminological combination, definition + definable, verb-object model, full abbreviations, incomplete abbreviations, mixed abbreviations.

\section{INTRODUCTION}

In the XXI century, when science and modern information technologies are rapidly developing, a number of innovations are observed in the field of linguistics. Today, terminology remains one of the most relevant areas of modern linguistic researches. It is safe to say that the reason for the popularity of terminology researches is that this field is not sufficiently studied.

The popularity of military terms and their transcendence beyond their initial use indicates not only the aggravation of the situation in the world political arena, but also the emergence of an everrenewing vocabulary. In many cases, the proliferation of lexical units related to military work is caused by the mass media. Therefore, it can be said that one of the important tasks facing linguists is to study the military terms in a comprehensive, in-depth way and fill the gap in this field.

Since the issue of the formation of military terms is also poorly studied, in our article we will try to give scientific conclusions by referring to the method of abbreviation, which is one of the methods of making these terms.

\section{Literature review}

Many linguists, including V.V. Vinogradov, G.O. Vinokur, A.S. Gerd, V.P. Danilenko, V.A. Zvyagintsev, O.N. Lapshina, V.M. Leychik, E.S. Nikitina, M.M. Pokrovskiy, A.A. Reformatskiy, A.Ya. Shaykevich etc. dealt with the issues of special vocabulary. The topic of military lexicon has also attracted the attention of many linguists. A.K. Abdulmanova, A.S. Budilovich, D.A. Garibyan, V.V. Ilenko, L.L. Kutina, 
CURRENT RESEARCH JOURNAL OF PHILOLOGICAL SCIENCES 2(12):

35-40, December 2021

DOI: https://doi.org/10.37547/philological-crjps-02-12-07

ISSN 2767-3758

(C)2021 Master Journals

Crossref do

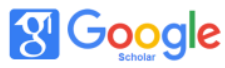

Accepted05th December, 2021 \& Published $10^{\text {th }}$ December, 2021

S.D. Ledyaeva, V.I. Maksimov, R.I. Sidorenko, F.P. Sorokoletov, I.S. Khaustova and others have dedicated their work to this topic.

The works of Chinese scholars Gao Liangfu, Wang Liping, Zhou Zumo, Zhang Jing, Jin Shaozhi, Zhu Dexi, Zhang Shilu, Li Jinxi, Liu Shiru, Lu Zhiwei, Gao Mingkai, Zhang Shoukan and others are devoted to the study of specific terminology.

As important sources on the subject, it is possible to highlight I.D. Klenin's “Military vocabulary of modern Chinese. Theoretical substantiation of the Chinese-Russian technical and military dictionary", "On some features of the Chinese military vocabulary”, I.D. Klenin, V.F. Shichko's “Lexicology of the Chinese language" and others.

\section{RESEARCH METHODOLOGY}

Words in a language, in particular terms, are formed in two different ways: based on the internal capabilities of the language and by assimilating ready-made language units from other languages. In turn, these two paths combine several methods. According to the morphological, lexical, phonetic features of languages, the productivity of word formation methods in different languages also differs from each other [1].

Abbreviation is one of the most common ways of word formation in Chinese. This method belongs to the type of word formation using the internal capabilities of the language. There is an increasing use of words constructed in this way in military terminology. Of course, abbreviations are an important part of Chinese lexicon. It would not be a mistake to say that Chinese abbreviations differ from ordinary words in that they serve as an independent part of speech.

A. Khojiyev explained the terms "abbreviatura" and "abbreviation" as follows: Abbreviation (lat. Abbrevio - I shorten) - abbreviation. Abbreviation (Italian. Abbreviatura < lat. Abbrevio - abbreviated) - abbreviations. Abbreviations - 1. Words formed by adding certain parts of the components of the phrase: PDP (People's Democratic Party), NUU (National University of Uzbekistan), etc.; 2. An abbreviated expression of a word in a particular form is a conditional abbreviation: et cetera - etc, A.K. - Abdullah Kadiri [2].

In the creation of abbreviations, emphasis is placed on hieroglyphs that reflect the main meaning. For this reason, the acronym is inextricably linked to the phrase. Whether or not a phrase becomes an abbreviation depends, firstly, on the fact that the phrase is used extensively and frequently. For example, the PRC (People's Republic of China), CPC (Chinese Communist Party), NPC (National People's Congress), PLAC (People's Liberation Army of China) etc. [3]

Today, the Chinese have a tradition of giving certain words and numbers additional meaning in addition to their original meaning. For example, 8 ("wealth"), 4 ("death"), and so on.

Abbreviation is the omission of individual components from complex lexical units, thereby simplifying these lexical units. In recent years, simplification of the complex structure of words and phrases has been widely used in Chinese military lexicon. Abbreviation depends in many ways on the number of syllables in abbreviated lexical units [4].

In Chinese, abbreviations are divided into two types: simple abbreviations (简称 jiănchēng) and synthetic abbreviations (合成 héchéng). Each type includes several models in its place [5].

According to researchers Kachalova K.G., 
CURRENT RESEARCH JOURNAL OF PHILOLOGICAL SCIENCES 2(12):

35-40, December 2021

DOI: https://doi.org/10.37547/philological-crjps-02-12-07

ISSN 2767-3758

(C)2021 Master Journals

Crossref do

gil Google

Accepted05 ${ }^{\text {th }}$ December, 2021 \& Published 10 ${ }^{\text {th }}$ December, 2021

Rudometova A.Y., Kapitonova N.S., it is advisable to divide Chinese abbreviations into the following types:

1. Abbreviations (简称 jiănchēng).

2. Abbreviations of the cut type.

3. Abbreviations of the generalized type

4. Abbreviations with letters (字母词 zìmŭcí)

5. Digital abbreviations (数字密码 shùzì mìmă) [6].

\section{AnAlysis AND RESUlts}

Based on the above data, we will try to analyze the shear models of military terms with three or more syllables. There are two main categories of terminological combinations:

1) definition + definable model units;

2) verb + object model units.

Definition + definable model units. Most of the abbreviated terms are based on this model.

Three-syllable terms. The abbreviation of threesyllable terms always leads to the formation of twosyllable words.

Model 1. In this case, the second syllable often falls: 主力炮 zhǔ [lì] pào - "main weapon" (主炮).

Model 2. In rare cases, the first joint is omitted. For example: 飞机场 [fēi] jīchăng - "airport" (机场).

The last joint is rarely omitted. This is because it performs a word-forming function, such as suffixes, and its omission usually results in a loss of meaning of the three-syllable term. For example, the terms 火药筒 huǒyàotǒng - "grain" and 子弹夹 zǐdànjiā "cartridge clip" mean "gunpowder" (火药) and "bullet" (子弹) without the final components. In Chinese, words that usually consist of a two-syllable definition and a one-syllable definable are abbreviated.

Four-syllable terms. The abbreviation of the foursyllable term results in the omission of one or two syllables. There are several manifestations of this:

Model 1. 1 and 2-components: 无线电台 [wúxiàn] diàntái - "radio station" (电台);

Model 2. 1 and 2-components: 战争俘虏 [zhàn]zhēng [fú]lǔ - "prisoner of war" P.O.W. (争虏);

Model 3. 1 and 4-components: 发射速度 [fā]shè sù [dù] - "rate of fire" (射速);

Model 4. 2 ва 3-components: 炮兵学校 pào[bīng xué]xiào - "artillery school" (炮校);

Model 5. 2 and 4-components: 政治委员 zhèng[zhì] wěi[yuán] - "commissar" (政委);

Model 6. 3 and 4-components: 总政治部 zǒng zhèng[zhìbù] - "General Political Department" (总政);

Model 7. 3-component: 自行火炮 zìxíng [huǒ]pào “self-propelled gun” (自行炮).

Although the abbreviated models of four-syllable terms are different, the essence of this process is that the abbreviated units are divided into two: independent and subordinate bases. This is followed by a shortening of the semantically insignificant joints. The result is a two-syllable abbreviation used in its original meaning or in the sense of abbreviated syllables.

Four-syllable terms consist of two two-syllable or one and three-syllable components. In the first case, their abbreviation leads to the appearance of complete abbreviations consisting of two cut cores (model 5). An example of this is the making of the abbreviation 后勤 hòuqín from 后方勤务 hòufāng qínwù - "post-military service". In the second view, incomplete abbreviations are formed, which fully reflect the truncated core of a single-articulated core and a truncated component (model 6). For example, the abbreviation 总参 zǒngcān is formed of

总参谋部 zǒng cānmóu - "headquarters" [4].

According to I.D. Klenin, the most effective model of abbreviation of four-syllable terms is model 5 $(60 \%)$. The second place is taken by the 4 th model. The contraction of the first and third components (model 2) is less common than the rest [4]. 
CURRENT RESEARCH JOURNAL OF PHILOLOGICAL SCIENCES 2(12):

35-40, December 2021

DOI: https://doi.org/10.37547/philological-crjps-02-12-07

ISSN 2767-3758

(C2021 Master Journals

Crossref do

81 Google

Accepted05 ${ }^{\text {th }}$ December, 2021 \& Published 10 ${ }^{\text {th }}$ December, 2021

It is worth mentioning the Model 7. This type of shortening can be called incomplete cuts. The peculiarity of this model is that such abbreviations consist of a complete base (determinant) and a truncated base (defined). For example, 定时炸弹 dìngshí [zhà]dàn - "delayed action bomb; time bomb" (定时弹).

An interesting aspect of this type of abbreviation is that we can observe the tendency to turn the last syllable into a word-forming semi-suffix and then into a suffix. It is in the constructions that the first two elements represent the main individual character of the object, and the last element has a general classifying meaning, that semi-suffixes are formed, such as 机 jī - "machine, mechanism" and弹 dàn - "projectile". For example, in four-syllable determinative terms 传家炮弹 chuánjiā pàodàn “armored piercing projectile" and 直升飞机 zhíshēng fēijī - "helicopter" the omission of the third syllables 机 $\mathrm{j} \overline{1}$ and 弹 dàn leads to an expansion of their semantic boundaries.

They are more abstract than their two-syllable equivalents - 炮弹 pàodàn - "artillery shell" and 飞机 fēijī - "airplane". In particular, they will be able to join not only the names of different types of shells and planes, but also a large number of cores that form lexical-semantic series of words denoting different cartridges, bombs, grenades, machines, apparatus, tools, instruments and other names. These joints, like the appendages, follow the twojoint cores and are not used independently [4].

Verb + object model units. In addition to the descriptive model terms, terminological combinations in the four-syllable verb + complement model are also used. For example, 埋设地雷 - mái[shè dì]léi - “to set up mines" (埋雷); 突破包围 tú[pò bāo]wéi - to “break through" (突围). This type of abbreviation corresponds to model 4 (drop of components 2 and 3).

Five-syllable terms. When five-syllable units are abbreviated, three and sometimes two syllables are dropped. In the first case, the formation of the full abbreviation takes place mainly on a single model:

1- model. Components 2，4，5: 防空司令部] fáng[kōng] sī[lìngbù] - "air defense command” (防司), 军事委员会 jūn[shì] wěi[yuánhuì] - "military council" ;

2- model. Components 1 and 2: 焕然导火线 [huànrán] dǎohuǒxiàn - "radiant fuse" (导火线);

3- model. Components 1 and 4: 飞机降落兵 [fēi]jī jiàng[luò]bīn - "landing troops" (机降兵);

4- model. Components 2 and 3: 短期迅练班 duăn[qí xùn]liànbān - "fast courses" (短练班);

5- model. Components 2 and 4: 高射炮兵师 gāo[shè] pào[bīng]shī - «anti-aircraft artillery division» (高炮师);

6- модель. Components 3 ва 4: 内燃发动机 nèirán [fādòng]jī - "internal combustion engine" (内燃机).

Five-syllable terms usually consist of a head and two levels of syllables. In the function of the main part - comes the last link, which has an abstractclassification feature. From a grammatical point of view, it is definite. The role of the secondary part is served by the remaining joints that form the joint determinant.

Six-syllable terms. As a result of the abbreviations, these terms become two-syllable full abbreviations or four-syllable descriptive words. However, complete abbreviations with a three-joint structure are almost impossible to make.

The most common model for generating abbreviated equivalents of six-syllable phrases is to drop one of the components of the first syllable. For 
CURRENT RESEARCH JOURNAL OF PHILOLOGICAL SCIENCES 2(12):

35-40, December 2021

DOI: https://doi.org/10.37547/philological-crjps-02-12-07

ISSN 2767-3758

(C2021 Master Journals

Crossref do

81 Google

Accepted05 ${ }^{\text {th }}$ December, 2021 \& Published 10 ${ }^{\text {th }}$ December, 2021

example, 军事政治学校 jūn[shì] zhèng[zhì] xuéxiào

- "military-political educational institution" (军政学校); 直接支援炮兵 zhí[jiē zhī]yuán pàobīng

- “direct support artillery" (直援炮兵).

7 and more syllable terms. In the military lexical system, seven and more complex units are also abbreviated. In this case, the more complex the structure of the term, the stronger the tendency to abbreviate it, which in many cases also depends on the continuity of its use in the language. For example, 人民革命军事委员会 [rénmín gémìng] jūn[shì] wěi[yuánhuì] - "People's Revolutionary Military Council” (军委). However, the specific weight of military vocabulary with such a complex structure is much lower.

Mixed abbreviations. A special type of abbreviations is a lexical complex combination of words that are close to each other in terms of two or more meanings and have a common component. The result is lexical units whose first components have an equal syntactic relationship. For example, 指挥员 zhǐhuī yuán "commander" + 战斗员 zhàndòu yuán "warrior" = 指战员 zhǐzhànyuán "warriors and commanders"; 伤员 shāngyuán - "injured" + 病员 bìngyuán - "patient" = 伤病员 shāngbìngyuán "injured and sick"; 轻机枪 qīng jīqiāng - "light machine gun” + 重机枪 zhòng jīqiāng - "heavy machine gun" = 轻重机枪 "light and heavy machine guns".

\section{Conclusion}

The variety of abbreviated models does not indicate a lack of systematization in the process of abbreviating multi-syllable military terms. At the heart of this process are certain semantic and structural laws. Semantic laws are manifested in the preservation of the most important semantic components in the structure of the abbreviation, which allows a more accurate expression of the internal form of the abbreviated term. As a proof of our point, let us consider the meaning of the singlesyllable component, if we take the term 发射速度 fāshè sùdù - "shooting speed", which consists of two words with two syllables, let's look at what its one-syllable components mean:

发 fâ 1 . to throw, to fly, to throw; 2. to send, dispatch; 3. to pay, give; 4 . take action;

射 shè to shoot;

速 sù 1 . speed, soon; 2. to summon, to invite;

度 dù 1 . norm, measure; 2. degrees; 3. law, system; 4. behavior.

The semantic analysis of these components shows that the semantic structure of the term "shooting speed" is relatively fully expressed by the syllables 射shè and 速 sù. The remaining components, because of their ambiguity, hide the root of the concept in an abbreviated form. Therefore, we conclude that combinations of other components, such as 发速 fāsù, 射度 shèdù, 发度 fādù, do not better express the inner meaning of the term.

When comparing the two major categories of abbreviations in the military lexicon system: definition + definable and verb + object models, we can see that most of the terms presented in the article are formed by the very first model. In conclusion, it can be said that abbreviation is a common method in Chinese, and the process of abbreviation is characterized not only by general laws but also by specific aspects.

\section{REFERENCES}

1. Mustafaeva S. Formation and development of the system of Chinese linguistic terms. Morography. - T .: "SHARQ", 2016. - 72-p.

2. Hojiev A. Annotated Dictionary of Linguistic Terms. - $\mathrm{T}$.: "National Encyclopedia of Uzbekistan", 2002. - p. 9, 142. 
CURRENT RESEARCH JOURNAL OF PHILOLOGICAL SCIENCES 2(12):

35-40, December 2021

DOI: https://doi.org/10.37547/philological-crjps-02-12-07

ISSN 2767-3758

(C)2021 Master Journals

crossref do) :810 Google

Accepted05 ${ }^{\text {th }}$ December, 2021 \& Published $10^{\text {th }}$ December, 2021

3. Nosirova S. Socio-political and diplomatic terminology of the Chinese language. -T .: «Yangi asr avlodi», 2011. - P. 96-97-s.

4. Klenin I. D. The Chinese-Russian military and technical dictionary. $\mathrm{M}$.: "Military publishing house", 1985. - P. 558-560.

5. Semenas A.L. Chinese vocabulary. - M .: "Muravey", 2000. - 57-p.

6. Kachalova K.G., Rudometova A.Y., Kapitonova N.S. The main types of abbreviations in the Chinese language // Modern studies of social problems. 2020.Vol. 12, No. 6. P. 107-116.

7. Li Xiaoge. Comparison of abbreviations in Russian and Chinese // Vestn. Peoples' Friendship University of Russia. Series: Theory of language. Semiotics. Semantics. 2017.Vol. 8, No. 2. P. 454-463.

8. Sageeva Y.P. Chinese compound words as a special part of the Chinese vocabulary // Young scientist. Series: Philology, Linguistics. 2015. No. 11 (91). P. 1681-1683

9. Strelkovsky G.M. Theory and practice of military translation. German. M .: Voenizdat, 1979. - P. 177-178.

10. Klenin I.D., Shichko V.F. Lexicology of the Chinese language. - M .: Vostochnaya kniga, 2013 .- P. 70-77.

11. Klenin I. D. Some features of the Chinese military vocabulary. - M .: Voenizdat, 1968 .P. 557-564.

12. Klenin I. D. Military vocabulary of modern Chinese. Theoretical substantiation of the "Chinese-Russian technical and military dictionary." - M.: VIIYa, 1970. - P. 32-37. 